\title{
Building and Health: Mapping the Knowledge Development of Sick Building Syndrome
}

\author{
Mengmeng Wang ${ }^{1}$, Lili $\mathrm{Li}^{1}$, Caixia Hou ${ }^{1,2}$, Xiaotong Guo ${ }^{1,2}$ and Hanliang Fu ${ }^{1,2, *(1)}$ \\ 1 School of Management, Xi'an University of Architecture and Technology, Xi'an 710055, China; \\ wangmengmeng@live.xauat.edu.cn (M.W.); 2009211650@xauat.edu.cn (L.L.); houcx@xauat.edu.cn (C.H.); \\ guoxiaotong@xauat.edu.cn (X.G.) \\ 2 Laboratory of Neuromanagement in Engineering, Xi'an University of Architecture and Technology, \\ $\mathrm{Xi}^{\prime}$ an 710055, China \\ * Correspondence: fuhanliang@xauat.edu.cn
}

Citation: Wang, M.; Li, L.; Hou, C.; Guo, X.; Fu, H. Building and Health: Mapping the Knowledge Development of Sick Building Syndrome. Buildings 2022, 12, 287. https://doi.org/10.3390/ buildings12030287

Academic Editor: Derek ClementsCroome

Received: 24 January 2022

Accepted: 25 February 2022

Published: 2 March 2022

Publisher's Note: MDPI stays neutral with regard to jurisdictional claims in published maps and institutional affiliations.

Copyright: (C) 2022 by the authors. Licensee MDPI, Basel, Switzerland. This article is an open access article distributed under the terms and conditions of the Creative Commons Attribution (CC BY) license (https:// creativecommons.org/licenses/by/ $4.0 /)$.

\begin{abstract}
At present, with more and more attention paid to the impact of buildings on the health and well-being of occupants, sick building syndrome (SBS) has become a global concern. Since the introduction of SBS by the World Health Organization (WHO) in 1983, thousands of research literatures have been published in this field. This paper systematically arranges knowledge development of SBS through bibliometric analysis, exploring the most influential countries, institutions, journals and scholars, as well as the main subject categories and keywords. Main path analysis (MPA) was used to list development trajectory under inheritance relationship of SBS knowledge, including symptom analysis, risk factors of SBS and the improved impact of ventilation on SBS and productivity. Furthermore, it is an emerging research trend to propose SBS solution in the building design stage.
\end{abstract}

Keywords: sick building syndrome (SBS); health; bibliometric; main path analysis

\section{Introduction}

During the COVID-19 pandemic, people have been spending 80 to $90 \%$ of their time working and living indoors, which not only increases people's concern about the impact of the building itself on human health, but promotes their pursuit of a healthy life $[1,2]$. As early as 2018, the World Health Organization (WHO) issued Housing and Health Guidelines to provide recommendations on how residential buildings can ensure people's safety and health, including insufficient living space (i.e., crowding), low room temperature and heat insulation, indoor injury risk and air pollution, among which indoor air pollution has attracted great concern [3]. The dramatic development of building technology has greatly improved energy-saving and comfort properties [4], but on the other hand it also requires an increasing amount of synthetic building materials which can lead to indoor air pollution accumulation, and is harmful to human health [5].

Indoor air pollutants come from both building materials and indoor human activities, and a serious consequence is the outbreak of building sick syndrome (SBS) [6]. It has been shown that the incidence of SBS is $57 \%$ in offices, $31 \%$ in university laboratories and $23-41 \%$ in university administrative buildings, and this has become a most common environmental health problem [7]. SBS was first introduced by WHO in 1983 and is defined as a collection of nonspecific symptoms for ill health caused by exposure to harmful agents associated with the occupancy of certain workplaces. The common symptoms of SBS include headache, mental fatigue, mucosal irritation, skin irritation, respiratory disorder, etc., which cause great harm to human productivity and health. In addition, one of the most important characteristics of SBS is the spatiotemporal association between disease and specific building; that is, symptoms will appear after working and staying in the building for a period of time but disappear spontaneously after leaving [8]. 
SBS has attracted great interest worldwide, and with in-depth research, many scholars have tried to summarize and sort out previous work and explore the knowledge development in the field of SBS. Vardoulakis and Jones reviewed the existing literature and found that the sources of pollutants causing SBS mainly include particulate matter (PM2.5 and PM10) generated by heating, cooking and smoking, etc.: nitrogen dioxide $\left(\mathrm{NO}_{2}\right)$; volatile organic compounds (VOCs); and polycyclic aromaric hydrocarbons (PAHs) $[9,10]$. Nordin and Tran reviewed SBS symptoms resulted from indoor pollutants and are categorized into three types: (a) general symptoms; namely, headache, nausea, dizziness, hoarseness, allergy, flu-like symptoms, respiratory disease, fatigue and inability to concentrate; (b) mucous membrane symptoms; namely, eye, nose, throat irritation and cough; (c) cutaneous symptoms, namely itching of skin, face, hands and scalp [11,12]. Fisk et al. has indicated a significant association between low ventilation rate and SBS as increasing natural ventilation can control humidity and remove indoor pollutants, which is an effective strategy to relieve SBS [13].

A previous review article has put forward in-depth opinions on the knowledge development of SBS, but all of these articles were carried out from a certain aspect of SBS. When facing thousands of research results, it is difficult to know the whole picture of knowledge development, and there is also a lack of quantitative systematic review of SBS knowledge and its development path using literature data. Therefore, based on the basic statistics and main path analysis (MPA) of bibliometrics, this paper attempts to reveal the knowledge development overview and path of SBS so that researchers in this field can comprehensively and objectively master knowledge basis and trajectory. At the same time, we also expect to provide valuable literature references to scholars in the fields of public health, architecture and sustainability, as well as to propose potential solutions to engineer for decreasing incidence of SBS, improving the health, well-being and productivity of indoor occupants.

\section{Materials and Methods}

\subsection{Methodology}

This study aims to explore knowledge basis and development trajectory by comprehensively and systematically reviewing literature in the field of SBS. Bibliometric was used for knowledge basis analysis while MPA was used for knowledge development trajectory analysis. MPA was first proposed by Hummon in 1898, referring to calculating weight of path link of direct citation network in order to determine the major development trajectory in scientific field [14]. In this paper, the author listed three algorithms for weight calculation, which were node-to-projection count (NPPC), search path link count (SPLC) and search path node pair (SPNP). In 2003, Batagelj further presented search path count (SPC) algorithm and integrated the above four algorithms in self-developed social network software Pajek, thus achieved the function of MPA [15].

MPA is based on the citation network, but the citation network construction is rarely mentioned in previous research. Such issue was also illustrated by Henrique on the authoritative journal Scientometrics in the field of informatics, in which he wrote "despite the popularity of MPA, the basic construction way of citation network has hardly been mentioned. In fact, all relevant papers used MPA on the basis of citation networks, but there were no details about its construction [16]". It can be seen that the existing main path papers focus on path count while leaving the underlying citation network to the readers to create [17], which is also a reason why the main math method is accepted by scholars but difficult to carry out in a wide range of applications.

Therefore, an algorithm for constructing citation networks is developed in this paper. The citation network is a model structured from the mutual citation relationship among a set of literatures, reflecting the inheritance and dissemination relationship of knowledge with literature as the carrier [18]. A basic principle of the algorithm is to use DOI to match citing articles and cited articles. To be specific, if DOI of a reference of $i$ th article is completely consistent with that of the $j$ th article, it indicates that the $j$ th article is cited in the $i$ th article. Then assign a value of 1 in the $j$ th row and $i$ th column in the citation 
matrix while assign a value of 0 to the item without citation relationship, and finally form a $0-1$ matrix with adjacency relationship. According to this principle, a standard data set based on three columns of (ID, P-DOI, C-DOI) in a field is established, in which the ID column refers to article number, the P-DOI column represents article DOI, and C-DOI is reference DOI. Figure 1 shows the general flow chart, on whose basis MATLAB software was applied for a corresponding algorithm in this paper and further implemented citation matrix construction.

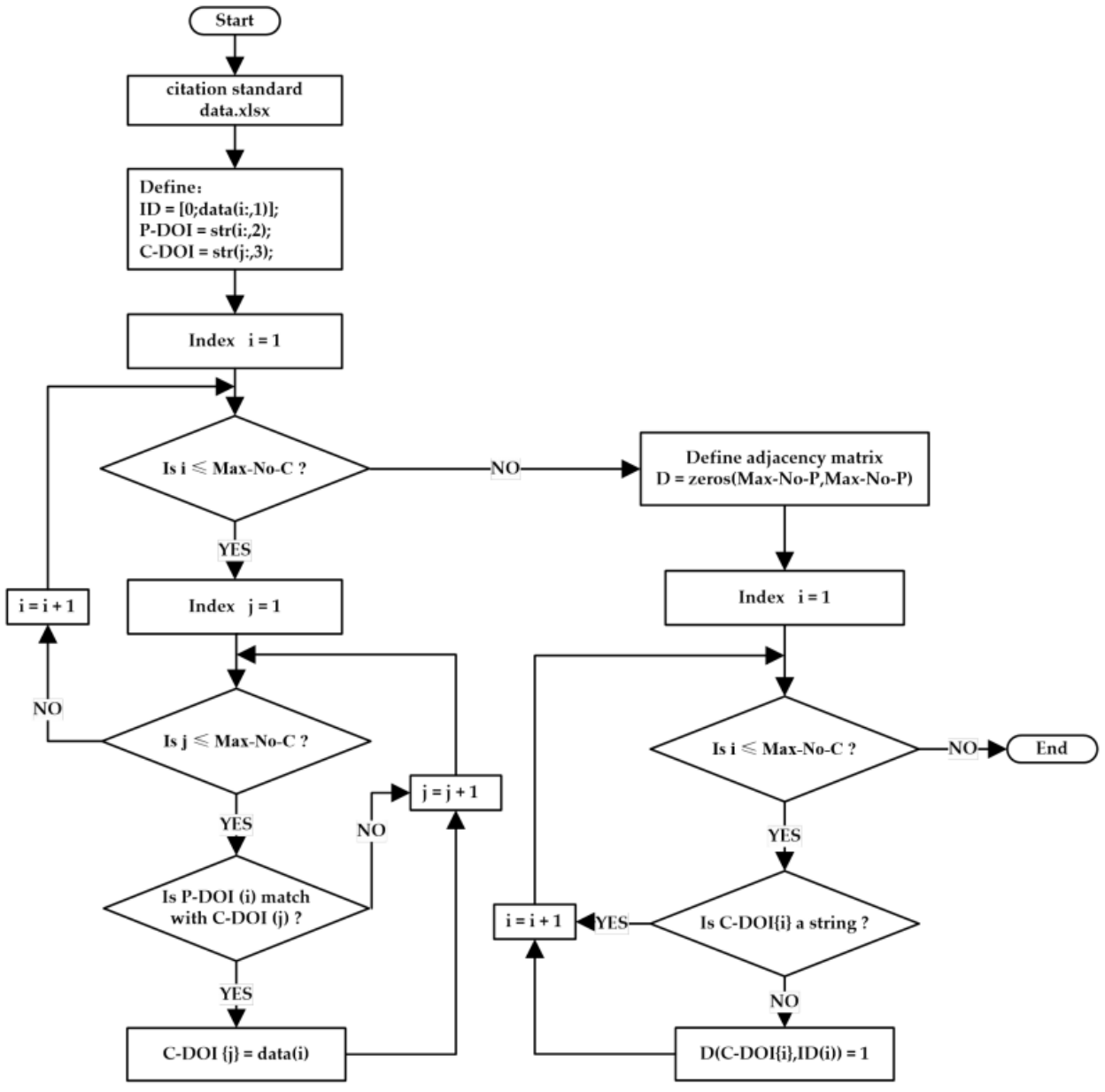

Figure 1. Flow chart of citation matrix construction.

\subsection{Data Retrieval}

Completeness and accuracy of literature data are the two key factors affecting bibliometric results. Three sources of SBS literature in this paper were the Science Citation Index (SCI-Expanded), the Social Science Citation Index (SSCI) and the Arts \& Humanities Citation Index (A\&HCI). All three are sub-databases of the Web of Science (WOS) citation index, with high-impact and high-quality journals in the fields of natural science, social science and humanities and arts, which ensures the quality and availability of literatures retrieved in SBS in this paper. "Sick building syndrome" was served as the subject term in the above database, and the search range included titles, abstracts and keywords, with language limited to English. As shown in Table 1, we finally obtained 1245 valid literatures in the SBS domain. Furthermore, bibliography data of 1245 were downloaded, including title, author, abstract, keywords, source publication, country, institution, year of publication, references and frequency of citations. 
Table 1. Search information in SBS domain.

\begin{tabular}{cc}
\hline Search Item & Search Content \\
\hline Search Topic & "sick building syndrome" \\
Search Language & English \\
Search Indexes & SCI-EXPANDED, SSCI, A\&HCI \\
Search Timespan & All years \\
Search Results & 1245 records \\
Data Acquisition Time & 28 October 2021 \\
\hline
\end{tabular}

Figure 2 indicates the research framework. First, determine the retrieval database and subject terms, followed by the collection of literature bibliographic data used for the subsequent SBS research and algorithm of citation matrix construction by MATLAB at the same time; further, use social network analysis software Pajek to construct a citation network. On this basis, we conducted this research in two aspects, one of which analyzed current knowledge base of SBS, including: (a) distribution analysis of literature quantity, citation, nations, institutions, authors and journals; (b) literature quantity and citation distribution analysis in subject that SBS belonged in; (c) keywords classification analysis. On the other hand, based on the main path calculation function in Pajek software, we extracted knowledge development trajectory of the entire SBS field through an algorithm of citation network construction. Simultaneously, a knowledge development trajectory at different time stages in the development process of SBS field was also extracted.

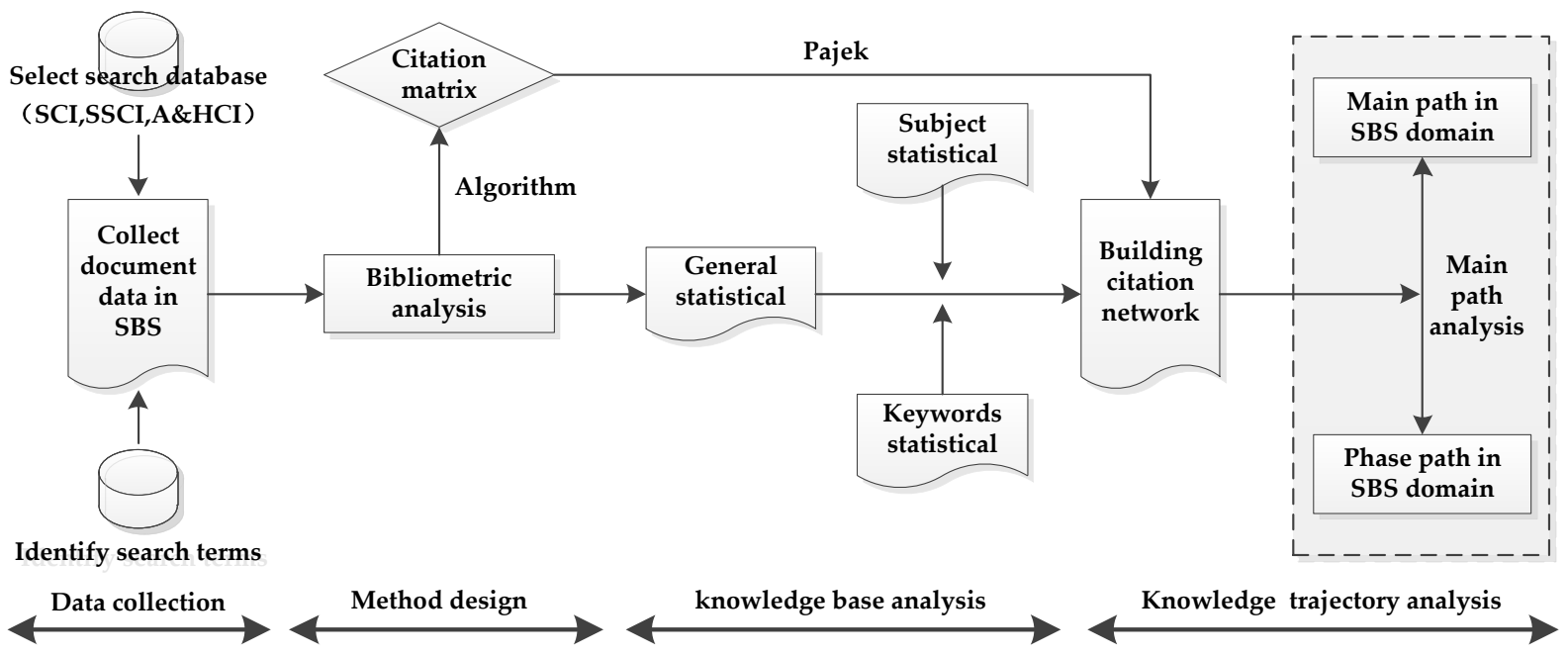

Figure 2. Research framework in SBS domain.

\section{Knowledge Base of SBS Research}

\subsection{General Statistical Analysis}

Basic bibliometric analysis results in Figure 3 were from quantitative statistics of bibliographic data in the field of SBS. As shown in Figure 3a, there has been a rapid development in academia until 1994 after WHO proposed SBS in 1983. Although publication numbers after 1994 were slightly fluctuated, it appeared to be a steady development trend as a whole. Also, despite SBS being a minority in academia according to publication numbers, it has always been a concern. Figure 3 b displays the distribution of references over the years, from which we can see that the highest citation number was 3315 in 1999, followed by 1997 and 2004. A possible reason could be the large amount of classic literature published in multiple fields in 1999, among which 7 articles were cited more than 100 times and the most cited paper was published by Jones AP with 862 citations. Figure $3 \mathrm{c}$ indicates the top ten countries in SBS publication, including five European countries, three Asian countries and two North American countries. The USA has the most publication number, followed by 
Sweden, while articles from Denmark have the highest citation numbers, so these countries have made important contributions to the development of SBS field.

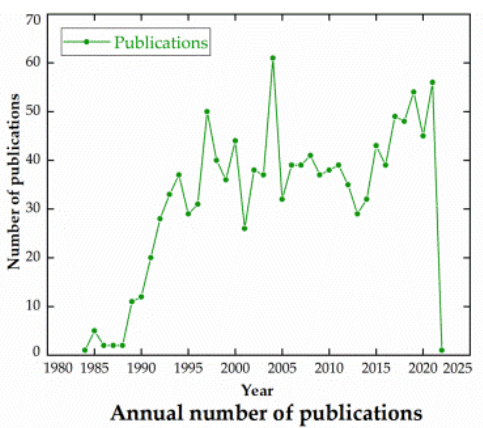

(a)

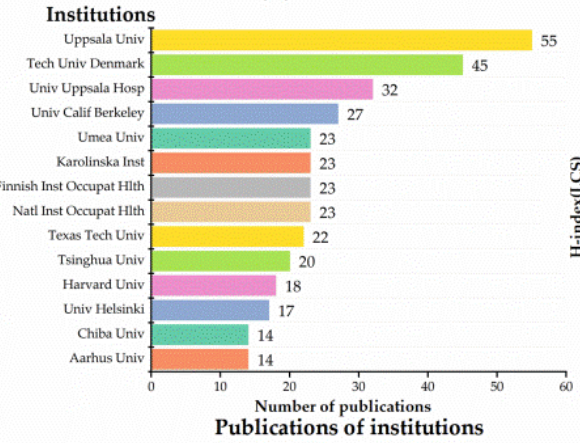

(d)

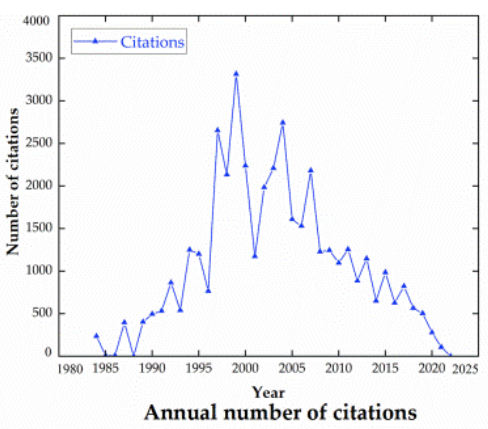

(b)

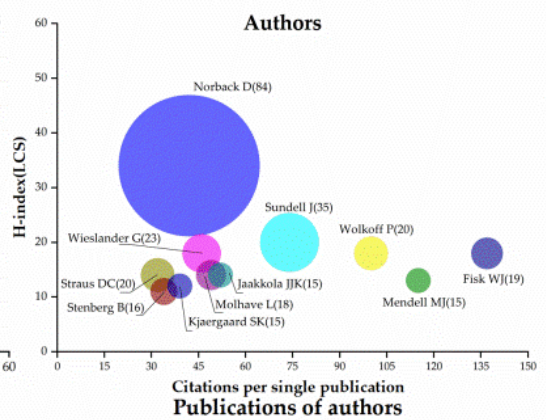

(e)

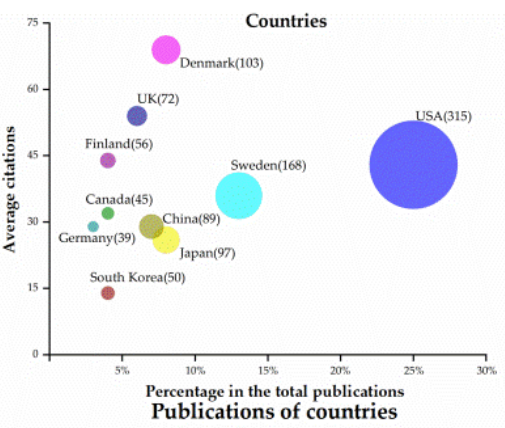

(c)

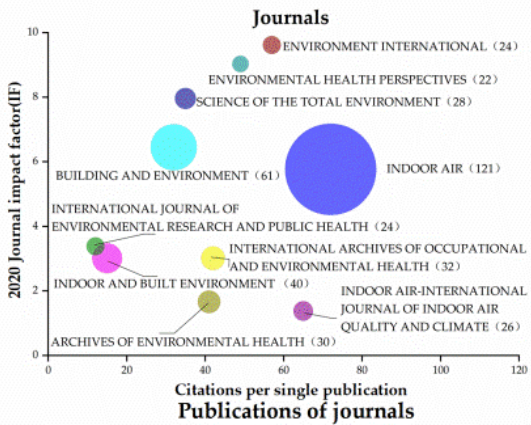

(f)

Figure 3. Basic bibliometric analysis of the SBS. (Note that the size of the nodes in (c,e,f) represents the difference in publication numbers. When the area of the nodes is larger, the publication number of the node is greater).

Figure 3d demonstrates the institutional distribution of SBS literature, with most of it coming from Uppsala University in Sweden, followed by Technical University in Denmark. Among the top 14 institutions, 9 are from European countries, 3 from North America and 2 from Asia, further confirming the research strength of Europe in SBS. Figure 3e shows the most influential scholars in the field of SBS. Norback D from Uppsala University has the largest number of papers with $\mathrm{H}$-index up to 34, and Fisk WJ from Lawrence Berkeley National Laboratory (LBNL) has the highest average citation. It is worth noting that differences in $\mathrm{H}$-index and publication number are within 2 among Wolkoff P, Fisk WJ, Mendell MJ, and Jaakkola JJK, which suggest the generally high quality of SBS articles by these scholars. Of the 11 core scholars, there are 3 each from Denmark, Sweden and the USA, and 1 each from China and England. Figure $3 \mathrm{f}$ represents core journals of SBS, of which Indoor Air ranks first on both publication number and average citation, and the journal is very popular with scholars in USA, Sweden, and Denmark. Likewise, Environment Health Perspectives is popular in USA, Building and Environment is popular in China and the USA, and Science of the Total Environment is popular in Sweden. Among the top ten journals, eight have an impact factor between 3 and 10, indicating that SBS has been focused and accepted by the mainstream academic community.

\subsection{Subject Statistical Analysis}

SBS is a disease produced when staying inside a building and has been mostly associated with indoor environmental characteristics, so research in this field involves multiple disciplines such as medicine, engineering construction and environment [8]. Figure 4 shows the main subjects related to SBS, including literature quantity and citation distribution of each subject and its distribution over the years in Figure $4 a, b$, respectively. Because SBS refers to the allergic and atopic reactions in the human body caused by poor indoor air 
quality, Medicine Generalinteral, Toxicology, Allergy and Immunology are the main four subjects in SBS research [12]. In addition, since the first SBS article in 1984, all articles were all published in medical journals until 1986, indicating that SBS was first found in medical treatment. Gradually, SBS attracted great attention from environmental science and engineering construction after three years of medical research on it.

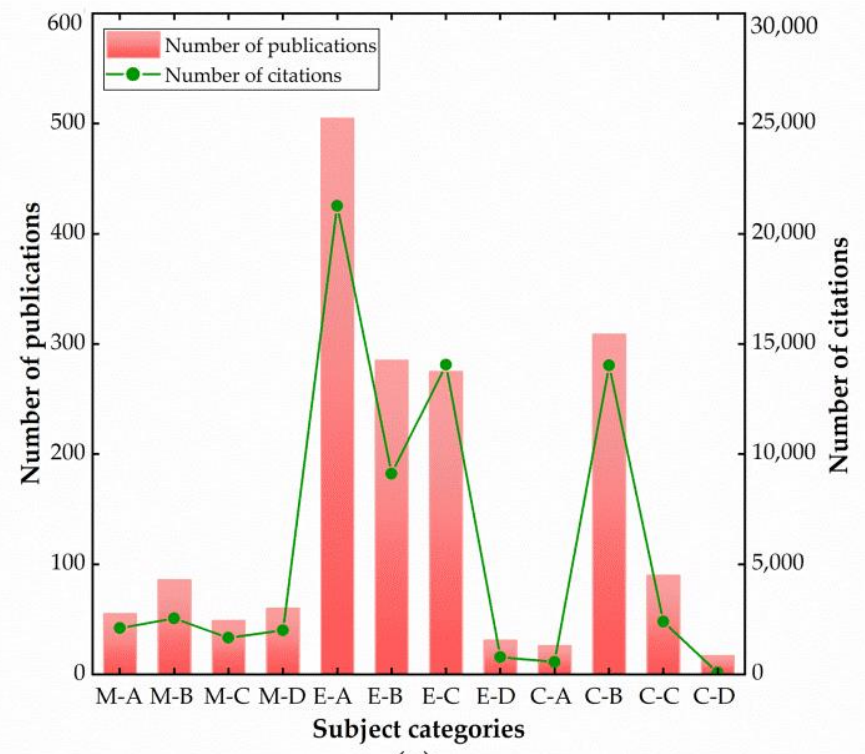

(a)

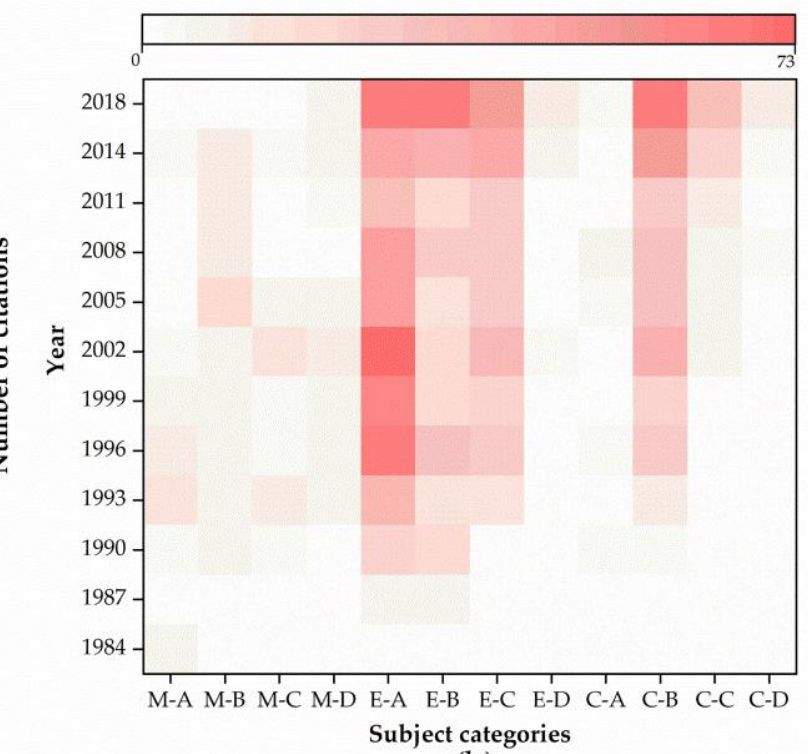

(b)

Figure 4. Subject Category analysis of the SBS. (a) Publications distribution; (b) Publications distribution over the years. (Note that $M$ represents the category of Medicine, so M-A, M-B, M-C and M-D, respectively, represent the subject of Medicine Generalinteral, Toxicology, Allergy and Immunology; Similarly E represents Environment, so E-A, E-B, E-C and E-D respectively represent Public Environmental Occupational Health, Environmental Science, Engineering Environmental and Energy Fuels; C represents Engineering Construction, so C-A, C-B, C-C and C-D respectively represent Engineering Mechanical, Construction Building Technology, Engineering Civil and Architecture).

Compared with medicine and engineering construction, there were significant more publications and higher citation in environmental science since 1987. Particularly, public environmental occupational health steadily ranked first over the years, suggesting that SBS caused by indoor environmental pollution, as well as its impact on occupational health, is a focus attention with this subject. Besides, since 1990, SBS has also gradually received the attention of engineering construction discipline with construction building technology ranks second in publication and citation numbers, proving that scholars have realized that the root cause of SBS lies in the building itself. Exploring the building system problems that cause SBS and developing new building technologies to improve indoor SBS symptoms have become hot topics.

\subsection{Keywords Statistical Analysis}

Figure 5 shows keywords statistics and a cluster distribution map in the SBS field, from which we can see home-, office- and school-building are widely studied building types, and women, children and office workers are more vulnerable to SBS due to longer indoor stays. Indoor environment quality problems are the main reasons for SBS, including poor air quality, air pollution, insufficient thermal comfort and air conditioning pollution, and thereby risk factors should consist of: (a) volatile organic compounds, formaldehyde, carbon dioxide and other air pollutants; (b) fungi, mold, bacteria and other microbial factors; (c) dust, bioaerosols, dampness and other microclimatic factors. Risk factors above will contribute to health issues: (a) asthma, allergy, respiratory symptoms; (b) multiple 
chemical sensitizations, hypersensitization pneumonitis, and chronic fatigue syndrome after staying in the room for a long period. Furthermore, environmental quality can also affect mental health; for example, cognitive performance will get worse among indoor personnel when air quality is poor or room temperature is high, thus leading to occupational stress or higher stress susceptibility [19]. Currently, building ventilation is considered as a powerful measure to create healthy and comfortable indoor environment in terms of frequent natural ventilation or mechanical ventilation improvement in order to effectively increase ventilation rates while reducing SBS incidence [20].
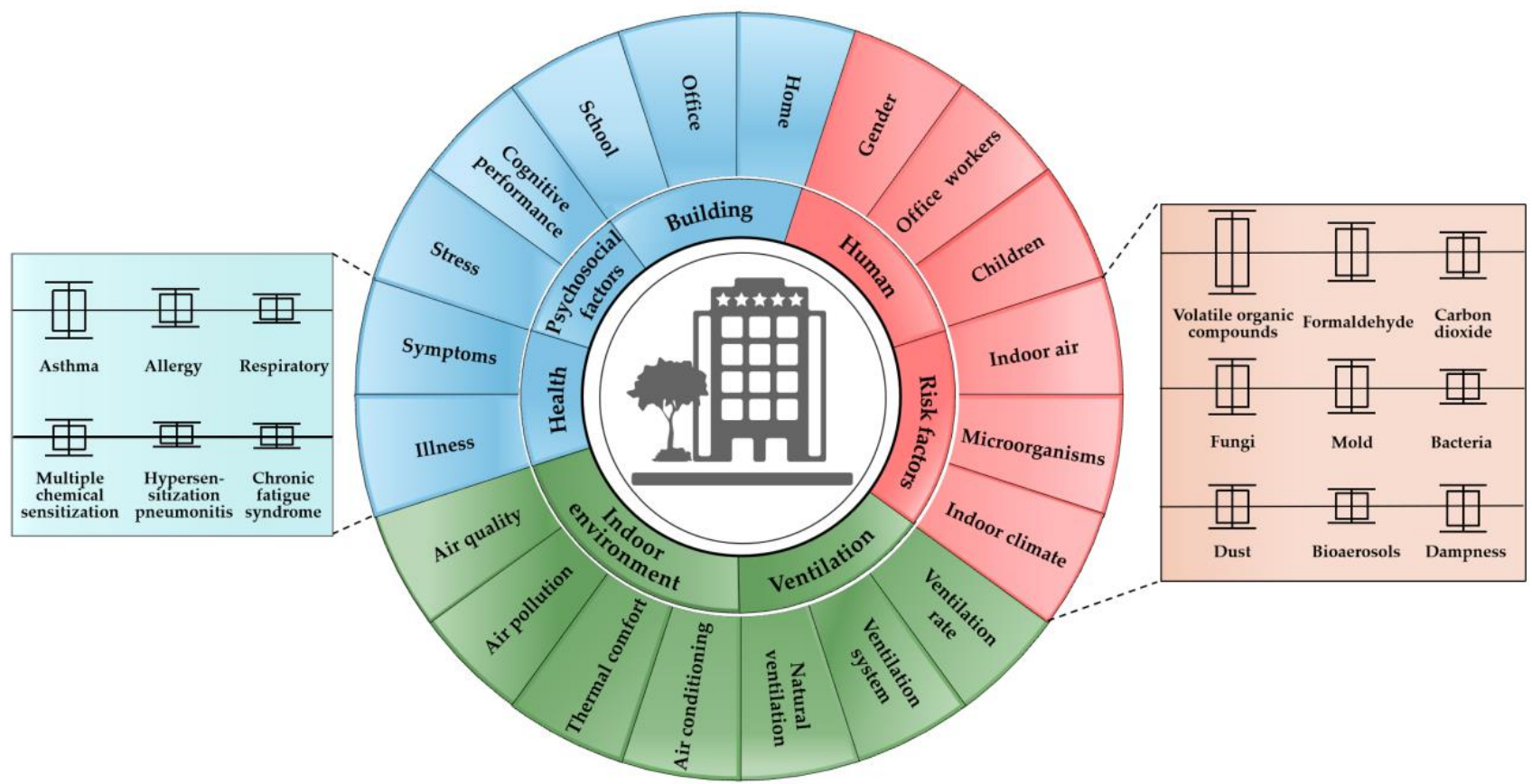

Figure 5. Keywords statistic and cluster of the SBS.

Figure 6 shows the co-occurrence network of core keywords in the SBS. The network nodes represent the keywords, and the nodes connection represents the co-occurrence frequency of the keywords in the article. The higher the frequency, the thicker the connection. From the figure, these core keywords are very closely related, and the keywords located in the middle are more connected to other keywords. Among them, health is connected to all other keywords, indicating that the purpose of SBS is to maintain the health and well-being of building occupants. Symptoms are also the focus of SBS, not only closely related to asthma, allergy and respiratory issues, but also often studied together with office, VOCs, dampness, etc. Similarly, research on VOCs often involves topics such as indoor air, formaldehyde, asthma, respiratory, ventilation, etc. In general, the distribution of keywords in Figure 6 is basically consistent with the clustering results in Figure 5, and in the co-occurrence network, the larger the node is, the more the node is located in the center of the network, and the more the node is valued. Therefore, health, symptoms, office, ventilation, air quality, VOCs and asthma, etc. have all been trending topics in the SBS field over the years. 


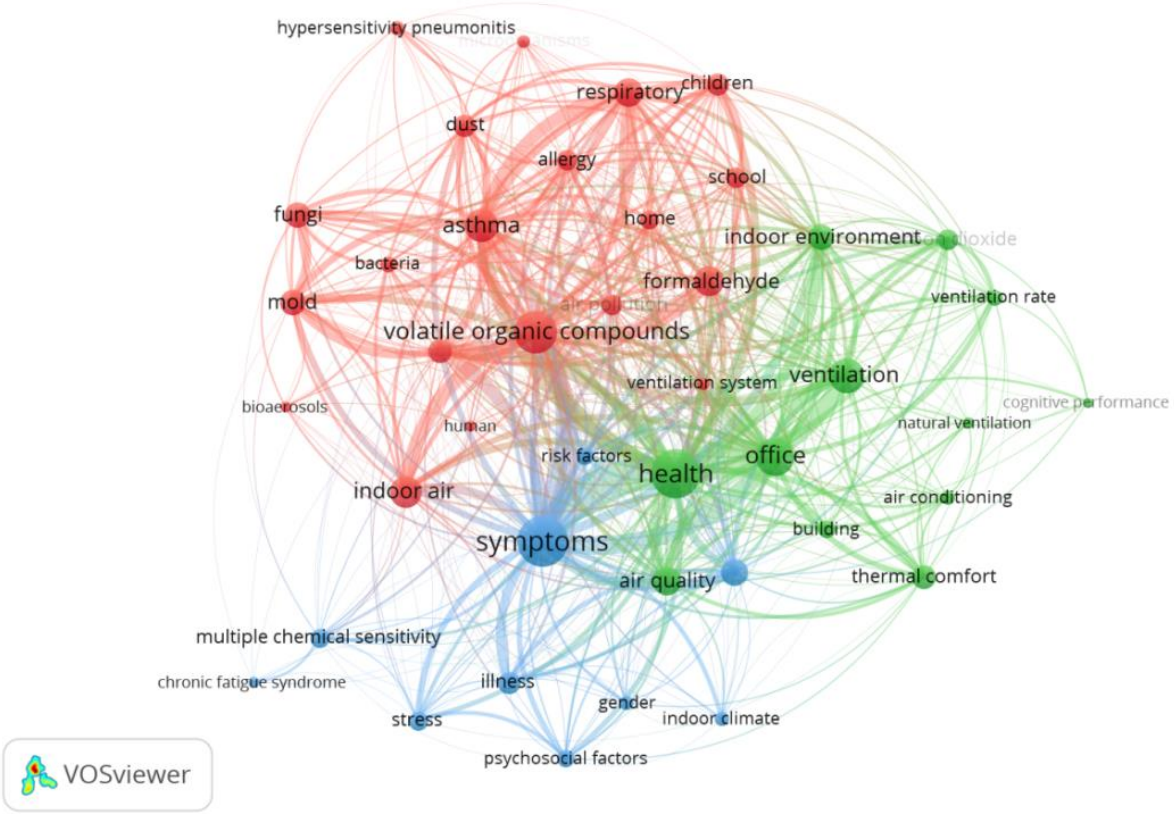

Figure 6. Keywords co-occurrence network of the SBS.

\section{Knowledge Development Trajectory of SBS Research}

\subsection{Construction of a Citation Network}

There is a citation relationship if an article is cited by another one, according to which a citation network will be formed in a field. The citation matrix is the cornerstone of visual display of citation network. According to literature data in the SBS field, the SBS-specific citation network can be obtained by using a MATLAB algorithm mentioned in the methods section. Furthermore, this citation network is imported into Pajek software and removed isolated nodes and components, and finally accomplishes construction of a citation network in the SBS field. Such a network contains 1036 literature nodes and 8647 directed links, with the average network density 0.0068 and average degree 14.14; that is, any node in the network is connected with 14 other nodes on average. Besides, the average shortest path is 3.12; that is, any node in the network only needs to pass through 3 nodes to be connected with another one. Clustering coefficient of the network is 0.109. All these prove a close inter-citation relationship between literatures in the SBS field.

Table 2 provides parameter information of important literature nodes in the citation network of SBS, including output degree, input degree and betweenness centrality, and literature name is expressed by the abbreviation of the first author and publication year. Output degree of literature nodes represents the number of links from one node to other nodes, reflecting the cited frequency of literature. The ten articles on the top of output degree value contain BURGE S, 1987, SKOV P, 1989, FINNEGAN MJ, 1984, etc., which are the classic highly cited literatures in the SBS field. Input degree of literature nodes represents the number of links from other nodes to one node. The ten articles on the top of input degree value contain Wolkoff P, 2013, Wargocki P, 2002, Ghaffarianhoseini A, 2018, etc., indicating that these articles cite a large number of professional SBS literatures and are likely to be authoritative review type articles in this field. Betweenness centrality refers to number of the shortest path through a node, reflecting whether the node is in the core position of the network. The ten articles on the top of betweenness centrality value contain Norback D, 2009, Wolkoff P, 2008, Burge PS, 2004, etc., which also further shows that these are the key articles connecting the entire knowledge network in the SBS field. 
Table 2. Parameter information of nodes in the citation network.

\begin{tabular}{ccccc}
\hline Output Degree & & Input Degree & \multicolumn{2}{c}{ Betweenness Centrality } \\
\hline Documents & Value & Documents & Value & Documents \\
\hline Burge S, 1987 & 147 & Wolkoff P, 2013 & 52 & Norback D, 2009 \\
Skov P, 1989 & 117 & Wargocki P, 2002 & 45 & Wolkoff P, 2008 \\
Finnegan MJ, 1984 & 113 & Ghaffarianhoseini A, 2018 & 40 & Burge PS, 2004 \\
Skov P, 1987 & 113 & Lim FL, 2015 & 38 & Kuhn DM, 2003 \\
Redlich CA, 1997 & 109 & Wolkoff P, 2008 & 33 & Wargocki P, 2002 \\
Skov P, 1990 & 93 & Lu C, 2016 & 32 & 0.006356 \\
Norback D, 1991 & 92 & Borchers AT, 2006 & 31 & Wolkoff P, 1997 \\
Norback D, 1990 & 91 & Norback D, 2009 & 30 & Wolkoff P, 2013 \\
Norback D, 1990 & 77 & Kuhn DM, 2003 & 30 & Hodgson M, 2000 \\
Apter A, 1994 & 74 & Wolkoff P, 2007 & 30 & Wolkoff P, 2006 \\
\end{tabular}

(Note: Please refer to Appendix A for specific documents information).

\subsection{Main Research Trajectory in the SBS Domain}

According to the established citation network in the SBS field, this section continues to conduct MPA to explore the knowledge development trajectory. Literature nodes extracted from the main path can reflect the inheritance of knowledge in the development process of SBS field. Specifically, on the basis of SBS citation network in Pajek software, in order to ensure a one-way non-circular network, it is first necessary to extract the maximum subnetwork and remove the loop in the network to form a standard network. Secondly, select the most commonly used SPC algorithm of MPA as the extraction basis for the key paths in the SBS field, then perform Key-Route Main Paths function in Pajek to extract global main path, and finally obtain the main path in SBS field, as shown in Figure 7. The figure shows 23 key literature nodes on the knowledge path in the SBS field which are highly cited, and the nodes of different colors represent the source of knowledge development, the intermediate inheritance of knowledge, and the convergence of the ultimate knowledge. At the same time, the node connection indicates the citation relationship between literatures. Thickness of the connection is calculated by the average citation frequency of adjacent nodes, and then the development of the field is differentiated from the initial nodes into five different paths step by step, which are Path A, Path B, Path C, Path D and Path E.

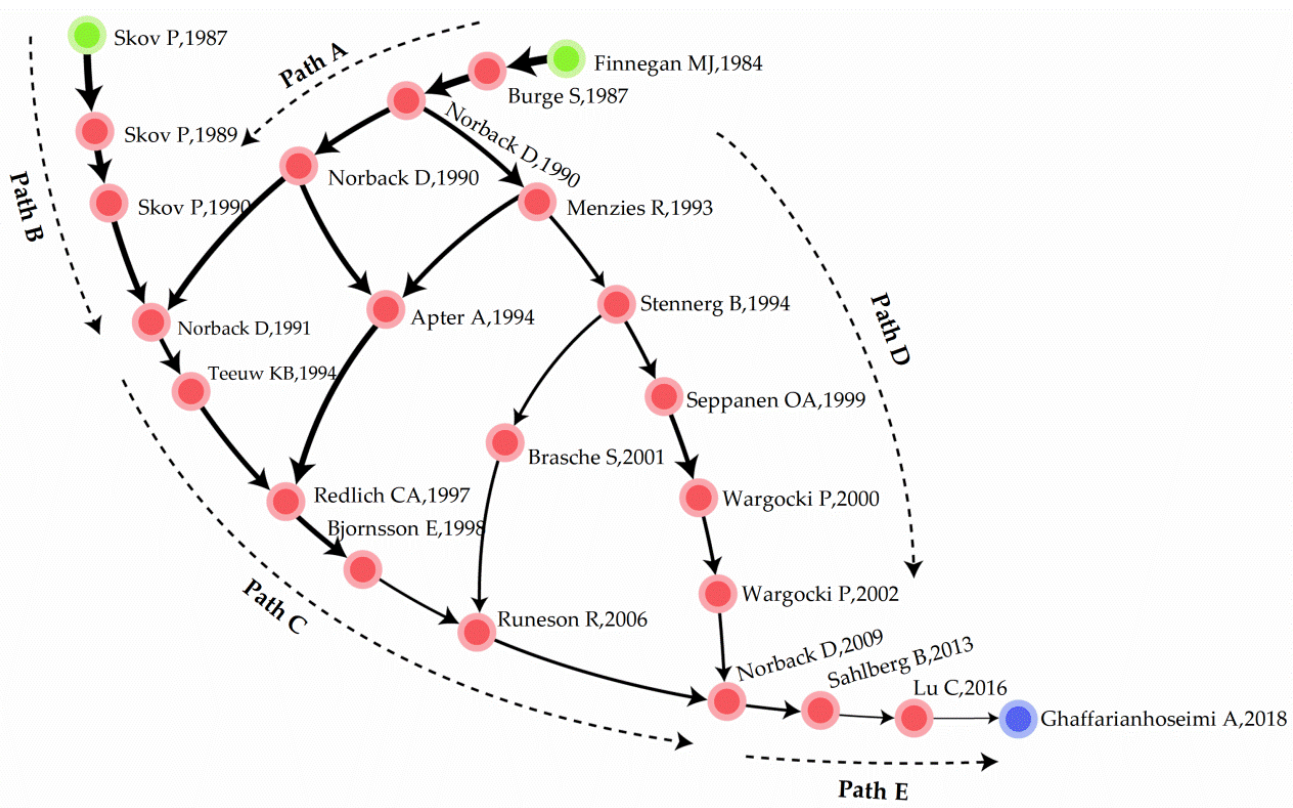

Figure 7. Main path analysis of the SBS [21-41]. 
From Path A, the first alcssic SBS article "The sick building syndrome-prevalence studies" was published in 1984, in which the author Finnegan et al. investigated the causes of SBS from an epidemiological perspective [21]. Burge et al. further corroborated such conclusion in his article that SBS is usually trigger by poor building heating, ventilation and air conditioning systems [22]. Since then, Norback et al. proposed that indoor temperature and carbon dioxide concentration are the key factors for the generation of SBS in 1990 [23], and volatile organic compounds, respirable dust in another article of the same year [24]. Also from Path B, symptoms such as headache, mucosal irritation, and fatigue were found to be related to the type of work in Skov's survey in 1987 [25], the prevalence of workrelated mucosal symptoms and general symptoms had a significant relationship with gender in 1989 with the same author [26], and the occurrence of SBS was related to gender, allergies, personality traits, work environment, occupational stress, room temperature, humidity, indoor air pollution in the article published in 1990 [27]. Accordingly, Path A and Path B converge at the same literature node (i.e., Norback D, 1991), where there was a summary of personal factors, occupational factors, psychosocial factors, building factors, and building-related factors are important factors responsible for the increased prevalence of SBS on the basis of existing research [28].

From Path C, on the basis of the existing research of [28], Teeuw et al. found that gramnegative bacteria and endotoxins in indoor air are also factors triggering SBS disease after investigation in 1994 [29]. Later in 1997, Redlich et al. also proved that the reproduction of microorganisms such as fungi, bacteria, and viruses can lead to diseases related to SBS, while the article also speculated that job satisfaction or job stress may affect the perception of SBS [30]. The above speculation was confirmed by Bjornsson in 1998 by anxiety and depression at work were important predictors of general symptoms of SBS based on questionnaires, that is, psychosocial stressors might make individuals more vulnerable [31]. Therefore, subsequent studies have mostly explored the relationship between psychosocial work environment and SBS, and Runeson et al. believed the reporting of SBS symptoms can be resulted from poor psychosocial environment (e.g., high work requirements, low job control and low job support rate), low satisfaction with the work environment, mental stress, health-related concerns and personality traits (e.g., neuroticism) [32].

From Path D, as early as 1993, Menzies et al. tried to explore the relationship between ventilation intervention and SBS and concluded ventilation rate is not associated with symptom improvement through a multiple crossover experiment [33]. However, in 1994, the actual measured ventilation rate by Stenberg was significantly negatively correlated with perceived SBS symptoms; that is, increasing ventilation rate can improve perceived air quality and reduce the prevalence of SBS and intensity of clinical symptoms [34], which were consistent with later literatures. Seppanen et al. pointed out that nearly 20 studies have all shown that an increase in ventilation rate can effectively reduce the prevalence of SBS when reviewing studies on the relationship between ventilation rate, carbon dioxide concentration and human health in 1999 [35]. Since then, Wargocki et al. further indicated in his study in 2000 that increased ventilation rates can greatly improve office performance while improving SBS [36]. At the same time, in another article in 2002, he reviewed 105 articles on the health effects of building ventilation on indoor personnel, except for the same conclusion before, the risk of SBS symptoms was also found to be increased in buildings with air-conditioning systems compared to buildings with natural ventilation or mechanical ventilation, and improper maintenance, design, and operation of air-conditioning systems can lead to the prevalence of SBS [37].

From Path E, Path C and Path D converge at the same literature node (i.e., Norback $D$, 2009). As a review article, it systematically sorted out the risk factors of SBS symptoms and deeply analyzed interventions to reduce SBS such as ventilation [38]. Since then, Sahlberg et al. assessed the health effects of indoor microorganisms, MVOCs, plasticizers, as well as formaldehyde in Nordic buildings in 2013 and found that these were all risk factors responsible for indoor SBS symptoms in Nordic [39]. Lu et al. also launched a survey in China in 2016, noting that indoor mold or humidity, air pollution from redecoration, and 
poor ventilation conditions are key factors in the development of SBS symptoms in Chinese adults, especially women [40]. Obviously, mainstream research has focused on risk factors of SBS, and Ghaffarianhoseini et al. proposed a new direction in his new review article, "Sick building syndrome: are we doing enough?" in 2018. Ghaffarianhoseini believed that health and well-being are important aspects of people-oriented architectural design, and as the human body is an interacting biological system, the current SBS research should not only tap the risk factors, but also consider how to come up with solutions to reduce the risk factors of SBS in the design stage of buildings. Also, the solution should not limit to a single factor, but should consider the interaction of multiple risk factors related to health [41].

\subsection{Phased Research Trajectory in the SBS Domain}

Since SBS received attention from the academic community in 1984, this field has undergone 38 years of development so far with a total of 1245 relevant published articles. In Section 4.2 of this paper, knowledge development trajectory of the whole field of SBS has been analyzed. In order to further understand the trajectory of early, middle and current different time stages, this section equally divides this field into three time periods which are 1984-1996, 1997-2009, 2010-2022, and then establishes citation network of each stage, respectively. Also, we use the social network software Pajek to mine the knowledge path of each stage.

\subsubsection{Research Trajectory between 1984 and 1996}

There were 213 literatures published from 1984 to 1996 when SBS was in its early development stage, as shown in Figure 8. It can be seen that the same main knowledge development trajectory as that of Path A and B in Figure 6, further confirming the reliability of path extraction. The study focus shifted to risk factors of SBS after scholars recognized the impact of buildings on human health, from the earliest Finnegan, Skov to Norback and Teeuw. Besides, Gyntelberg et al. also found that physical, chemical and microbial characteristics of dust are significantly related to SBS, among which particulate matter and macromolecular dust in dust were related to mucosal symptoms, volatile organic components in dust were related to inattention and general malaise, and Gram bacteria in dust were related to general symptoms (e.g., fatigue, dizziness, headache, and inattention) [42]. In the same year, Nordstorm et al. carried out a study on the relationship between different indoor humidity and SBS during the heating season and found that an increase in air humidity could effectively reduce SBS symptoms through a control group experiment [43]. Stenberg et al. again proved in 1995 that women are more vulnerable to in-office SBS than men [34]. All of these studies have enriched the investigation of risk factors of SBS.

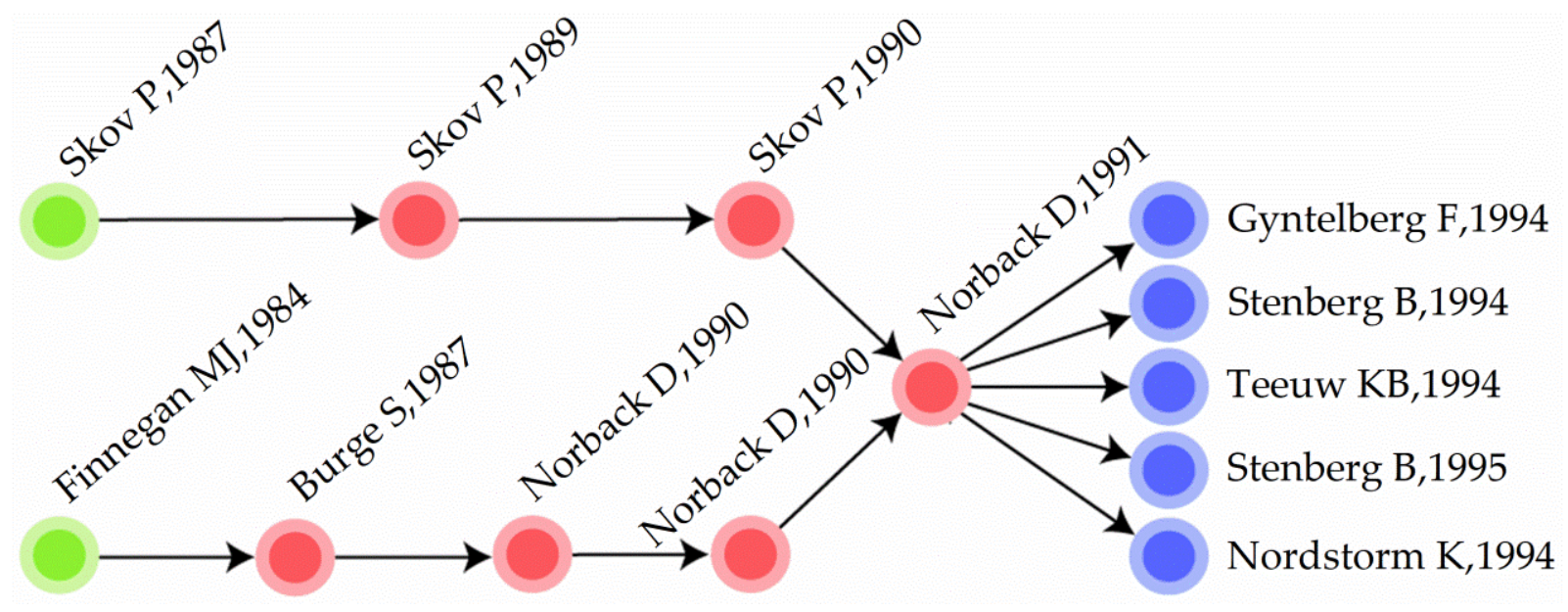

Figure 8. Phase path analysis of the SBS from 1984 to 1996 [21-29,34,42-44]. 


\subsubsection{Research Trajectory between 1997 and 2009}

There were 520 literatures published from 1997 to 2009 when SBS was in its stable development stage, as shown in Figure 9. It can be seen that the similar main knowledge development trajectory as that of Path C and D in Figure 6, indicating that indoor risk factors of SBS was still a main concern while exploring the improvement of SBS symptoms under different ventilation measures. In addition to the previously introduced literature nodes, Wargocki et al. designed a control group experiment and concluded compared with the indoor non-pollution group, the indoor pollution group is more likely to have SBS and lower productivity [44], which laid the foundation for his research in 2000 to investigate the relationship between ventilation rate and improvement of SBS symptoms and productivity. Apte et al. pointed out that an excess of indoor carbon dioxide significantly increases the incidence of SBS, but if ventilation rates are substantially increased, the prevalence of corresponding SBS symptoms could be reduced by $70 \%$ to $85 \%$ [45]. This paper predicts the improvement of SBS by ventilation in a quantitative way, providing data support for the appropriate SBS interventions.

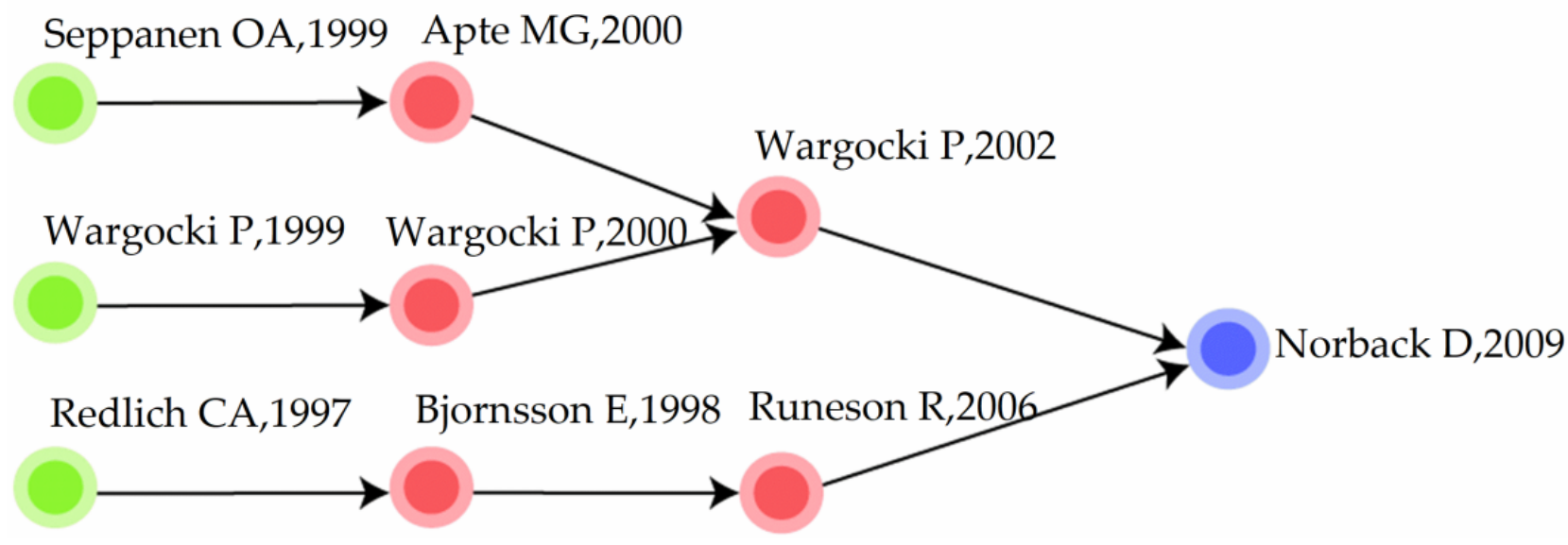

Figure 9. Phase path analysis of the SBS from 1997 to 2009 [30-32,35-38,44,45].

\subsubsection{Research Trajectory between 2010 and 2022}

There were 508 literatures published from 2010 to 2022 when SBS was in its mature development stage, as shown in Figure 10. It can be seen that there have been systematic studies on the epidemic symptoms of SBS in buildings, the risk factors of SBS, as well as how ventilation can improve SBS. On this basis, Takigawa et al. investigated the relationship between chemicals in residential buildings and SBS in Japan in 2010 and found that aldehydes and VOCs are risk factors associated with visual, nasal and ocular symptoms [46]. In the same year, Araki et al. further discovered that microbes can produce a range of VOCs (MVOCs), and short- or long-term exposure to such MVOCs may lead to mucosal irritation or more serious health issues [47]. Since then, Sahlberg et al. and Lu et al. also suggested that microorganisms, MVOCs, mold or humidity, air pollution from refurbishment, are the key factors of SBS. All of these studies contributed to a further improvement for the studies on SBS risk factors [39,40]. While in 2018, research of Ghaffarianhoseini discussed how to prevent the occurrence of SBS at the building design stage from a new perspective. Under this concept, Alwaer et al. believed that urban design should also pay attention to the impact on both physical and mental health. These two scholars have attracted much attention in the present and opened up a new direction for SBS research [48]. 


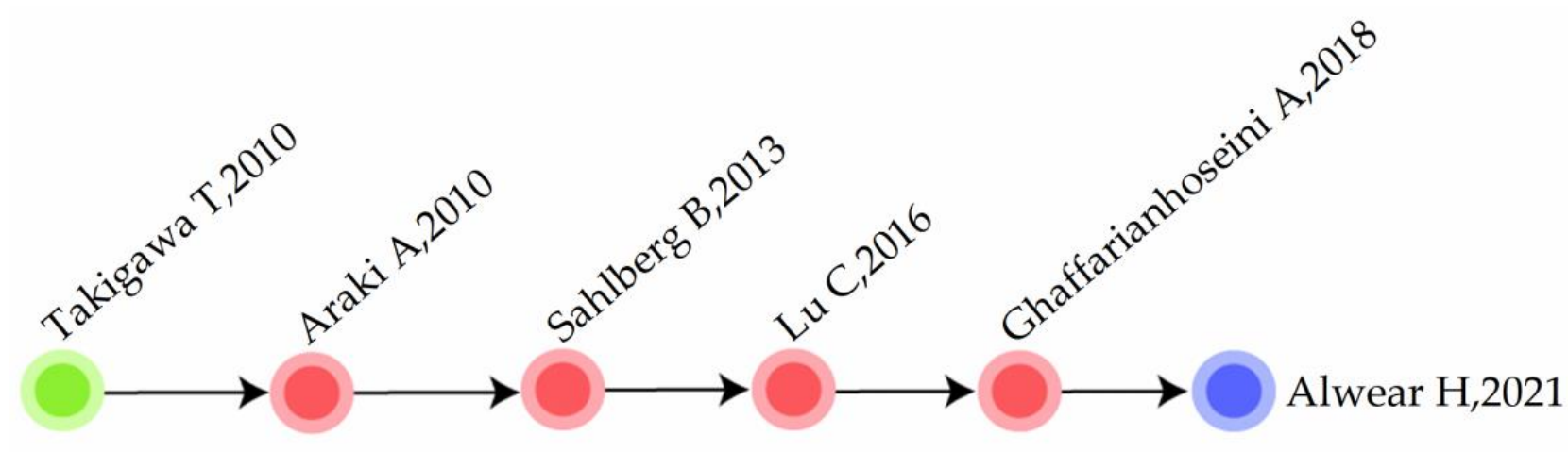

Figure 10. Phase path analysis of the SBS from 2010 to 2022 [39-41,46-48].

\section{Conclusions}

There is a growing global focus on the impact of buildings on health and well-being of occupants [49], especially on health issues regarding SBS associated with indoor environments. Thousands of articles have been published so far, not only because of the increasing number of overheating, inadequate ventilation and poor indoor air quality, but due to the growing consciousness of the role of building environment on human health. Therefore, this paper attempts to comprehensively grasp the knowledge development status and possible solutions of SBS through a systematic review. To this end, bibliometric was performed first to determine the influential countries/institutions/scholars/journals and keywords through analysis of an SBS knowledge base, and second, to determine the traditions and evolution trends of core SBS knowledge through analysis of SBS knowledge trajectory. Overall, the main conclusions are as follows:

(1) Knowledge base. SBS has experienced 38 years of development after first proposed in 1983. Research strength of the United States and Denmark is the strongest, while Uppsala University from Sweden should also not be underestimated. Norback D and Fisk WJ have the highest influence factor, and Indoor Air has the most publication number in this field. From the subject categories involved, SBS was first carried out in medical science, then environmental science after 1987 and engineering construction after 1990. From the research topics involved, the main concerns are physical and psychological diseases of women and children in families or offices and schools, including both corresponding symptoms (e.g., asthma, allergy, etc.) and triggered diseases (e.g., chronic fatigue syndrome, etc.). In addition, risk factors of SBS have also drawn attention, including air pollution, microbial and climatic factors and the improvement of SBS by increasing building ventilation.

(2) Knowledge development trajectory. Finnegan MJ published the first influential SBS article on British Medical Journal in 1984, investigating causes of SBS from an epidemiological perspective. Since then, various SBS knowledge trajectories have been developed, whether it is the whole domain knowledge trajectory or the phased knowledge trajectory at each stage. Generally speaking, mainstream research in this field has been focusing on the risk factors of SBS. Based on previous studies, scholars supplement risk factors of SBS step by step, which in summary include personal factors, occupational factors, psychosocial factors, building factors (e.g., VOC, formaldehyde and other pollutants) and building related factors (e.g., indoor dust, outdoor climate, etc.). Another research path related to interventions of SBS has shown that office work performance can be improved by different ventilation types (i.e., natural ventilation, mechanical ventilation, air conditioning, etc.) and ventilation rate. The latest research, on the other hand, believes that solutions of SBS should be committed at the architectural design stage with the purpose of making it more consistent with the behaviors, preferences, health and well-being of occupants, providing novel concept and development direction for the study of SBS. 
There are still some limitations in spite of there being an exhaustive and systematic survey of SBS knowledge development in this paper. First, MPA in bibliometric was conducted to mine SBS knowledge trajectory by simplifying the complex citation network into one or more simple paths. Although the nodal literatures on the path were all highly cited ones, not all highly cited literatures were contained due to the limitation of SPC algorithm. Second, highly cited literature identified in this paper were formed by mutual citation within the field, while some important articles widely cited by other related disciplines might be neglected. For example, "indoor air quality and health" by Jones AP in 1999 was cited 30 times in the field of SBS, but 862 times in WOS. Last, search terms in this paper only used "sick building syndrome". Considering the close relationship between SBS and a healthy building environment, indoor air quality and occupants' health, further research should expand research samples, as well as explore how buildings promote human health and well-being from the perspective of healthy buildings.

Author Contributions: Conceptualization, H.F. and M.W.; methodology, X.G.; software, C.H.; data curation, L.L.; writing—original draft preparation, M.W.; writing—review and editing, M.W.; funding acquisition, M.W. All authors have read and agreed to the published version of the manuscript.

Funding: This research was funded by the National Natural Science Foundation of China, grant number 72104192.

Institutional Review Board Statement: Not applicable.

Informed Consent Statement: Not applicable.

Data Availability Statement: The data presented in this study are available on request from the corresponding author. The data are not publicly available as the data also forms part of an ongoing study.

Conflicts of Interest: The authors declare no conflict of interest.

\section{Appendix A}

Table A1. Specific documents information of SBS.

\begin{tabular}{|c|c|c|c|}
\hline Documents & Title & Journal & DOI \\
\hline Burge S, 1987 & $\begin{array}{l}\text { Sick building syndrome-A study } \\
\text { of } 4373 \text { office workers }\end{array}$ & Annals of Occupational Hygiene & 10.1093/annhyg/31.4A.493 \\
\hline Skov P, 1989 & $\begin{array}{l}\text { Influence of personal } \\
\text { characteristics, job-related factors } \\
\text { and psychosocial factors on the } \\
\text { sick building syndrome }\end{array}$ & $\begin{array}{l}\text { Scandinavian Journal of Work } \\
\text { Environment \& Health }\end{array}$ & 10.5271/sjweh.1851 \\
\hline Finnegan MJ, 1984 & $\begin{array}{l}\text { The sick building } \\
\text { syndrome-prevalence studies }\end{array}$ & British Medical Journal & 10.1136/bmj.289.6458.1573 \\
\hline Skov P, 1987 & $\begin{array}{l}\text { The sick building syndrome in the } \\
\text { office environment-the danish } \\
\text { town hall study }\end{array}$ & Environment International & $10.1016 / 0160-4120(87) 90190-5$ \\
\hline Redlich CA, 1997 & Sick-building syndrome & Lancet & $10.1016 / S 0140-6736(96) 07220-0$ \\
\hline Skov P, 1990 & $\begin{array}{l}\text { Influence of indoor climate on the } \\
\text { sick building syndrome in an } \\
\text { office environment }\end{array}$ & $\begin{array}{l}\text { Scandinavian Journal of Work } \\
\text { Environment \& Health }\end{array}$ & 10.5271/sjweh.1772 \\
\hline Norback D, 1991 & $\begin{array}{l}\text { Environmental, occupational, and } \\
\text { personal factors related to the } \\
\text { prevalence of sick building } \\
\text { syndrome in the general } \\
\text { population }\end{array}$ & $\begin{array}{l}\text { British Journal of Industrial } \\
\text { Medicine }\end{array}$ & Unknown \\
\hline Norback D, 1990 & $\begin{array}{l}\text { Volatile organic-compounds, } \\
\text { respirable dust, and personal } \\
\text { factors related to prevalence and } \\
\text { incidence of sick building } \\
\text { syndrome in primary-schools }\end{array}$ & $\begin{array}{l}\text { British Journal of Industrial } \\
\text { Medicine }\end{array}$ & Unknown \\
\hline Norback D, 1990 & $\begin{array}{l}\text { Indoor air-quality and personal } \\
\text { factors related to the sick building } \\
\text { syndrome }\end{array}$ & $\begin{array}{l}\text { Scandinavian Journal of Work } \\
\text { Environment \& Health }\end{array}$ & 10.5271/sjweh.1808 \\
\hline
\end{tabular}


Table A1. Cont.

\begin{tabular}{|c|c|c|c|}
\hline Documents & Title & Journal & DOI \\
\hline Apter A, 1994 & $\begin{array}{l}\text { Epidemiology of the sick building } \\
\text { syndrome }\end{array}$ & $\begin{array}{l}\text { Journal of Allergy and Clinical } \\
\text { Immunology }\end{array}$ & 10.1016/0091-6749(94)90087-6 \\
\hline Wolkoff P, 2013 & $\begin{array}{l}\text { Indoor air pollutants in office } \\
\text { environments: Assessment of } \\
\text { comfort, health, and performance }\end{array}$ & $\begin{array}{l}\text { International Journal of Hygiene } \\
\text { and Environmental Health }\end{array}$ & 10.1016/j.ijheh.2012.08.001 \\
\hline Wargocki P, 2002 & $\begin{array}{l}\text { Ventilation and health in } \\
\text { non-industrial indoor } \\
\text { environments: report from a } \\
\text { European Multidisciplinary } \\
\text { Scientific Consensus Meeting } \\
\text { (EUROVEN) }\end{array}$ & Indoor Air & 10.1034/j.1600-0668.2002.01145.x \\
\hline Ghaffarianhoseini A, 2018 & $\begin{array}{l}\text { Sick building syndrome: are we } \\
\text { doing enough? }\end{array}$ & Architectural Science Review & $10.1080 / 00038628.2018 .1461060$ \\
\hline & $\begin{array}{c}\text { Sick building syndrome (SBS) } \\
\text { among office workers in a } \\
\text { Malaysian }\end{array}$ & & \\
\hline Lim FL, 2015 & $\begin{array}{l}\text { university-Associations with } \\
\text { atopy, fractional exhaled nitric } \\
\text { oxide (feno) and the office } \\
\text { environment }\end{array}$ & Science of the Total Environment & 10.1016/j.scitotenv.2015.06.137 \\
\hline Wolkoff P, 2008 & $\begin{array}{l}\text { "Healthy" eye in office-like } \\
\text { environments }\end{array}$ & Environment International & 10.1016/j.envint.2008.04.005 \\
\hline Lu C, 2016 & $\begin{array}{l}\text { Outdoor air pollution, } \\
\text { meteorological conditions and } \\
\text { indoor factors in dwellings in } \\
\text { relation to sick building syndrome } \\
\text { (SBS) among adults in China }\end{array}$ & Science of the Total Environment & 10.1016/j.scitotenv.2016.04.033 \\
\hline Borchers AT, 2006 & $\begin{array}{l}\text { Airborne environmental injuries } \\
\text { and human health }\end{array}$ & $\begin{array}{l}\text { Clinical Reviews in Allergy \& } \\
\text { Immunology }\end{array}$ & 10.1385/CRIAI:31:1:1 \\
\hline Norback D, 2009 & $\begin{array}{l}\text { An update on sick building } \\
\text { syndrome }\end{array}$ & $\begin{array}{l}\text { Current Opinion in Allergy and } \\
\text { Clinical Immunology }\end{array}$ & 10.1097/ACI.0b013e32831f8f08 \\
\hline Kuhn DM, 2003 & $\begin{array}{c}\text { Indoor mold, toxigenic fungi, and } \\
\text { Stachybotrys chartarum: } \\
\text { Infectious disease perspective }\end{array}$ & Clinical Microbiology Reviews & 10.1128/CMR.16.1.144-172.2003 \\
\hline Wolkoff P, 2007 & $\begin{array}{l}\text { The dichotomy of relative } \\
\text { humidity on indoor air quality }\end{array}$ & Environment International & 10.1016/j.envint.2007.04.004 \\
\hline Burge PS, 2004 & Sick building syndrome & $\begin{array}{l}\text { Occupational and Environmental } \\
\text { Medicine }\end{array}$ & 10.1136/oem.2003.008813 \\
\hline Wolkoff P, 1997 & $\begin{array}{l}\text { Are we measuring the relevant } \\
\text { indoor pollutants? }\end{array}$ & Indoor Air & $\begin{array}{c}\text { 10.1111/j.1600-0668.1997.t01-2- } \\
\text { 00003.x }\end{array}$ \\
\hline Hodgson M, 2000 & Sick building syndrome & $\begin{array}{c}\text { Occupational Medicine-State of } \\
\text { the Art Reviews }\end{array}$ & Unknown \\
\hline Wolkoff P, 2006 & $\begin{array}{c}\text { Organic compounds in office } \\
\text { environments-Sensory irritation, } \\
\text { odor, measurements and the role } \\
\text { of reactive chemistry }\end{array}$ & Indoor Air & 10.1111/j.1600-0668.2005.00393.x \\
\hline
\end{tabular}

\section{References}

1. Awada, M.; Becerik-Gerber, B.; Hoque, S.; O’Neill, Z.; Pedrielli, G.; Wen, J.; Wu, T. Ten questions concerning occupant health in buildings during normal operations and extreme events including the COVID-19 pandemic. Build. Environ. 2021, 188, 107480. [CrossRef]

2. Licina, D.; Yildirim, S. Occupant satisfaction with indoor environmental quality, sick building syndrome (sbs) symptoms and self-reported productivity before and after relocation into well-certified office buildings. Build. Environ. 2021, $204,108183$. [CrossRef]

3. World Health Organization. WHO Housing and Health Guidelines. Available online: https://www.who.int/publications/i/ item/9789241550376 (accessed on 20 December 2021).

4. Cheng, B.; Lu, K.; Li, J.; Chen, H.; Luo, X.; Shafique, M. Comprehensive assessment of embodied environmental impacts of buildings using normalized environmental impact factors. J. Clean. Prod. 2021, 334, 130083. [CrossRef]

5. Phillips, H.; Handy, R.; Sleeth, D.; Thiese, M.S.; Schaefer, C.; Stubbs, J. Taking the “LEED” In indoor air quality: Does certification result in healthier buildings? J. Green Build. 2020, 15, 55-66. [CrossRef]

6. Baloch, R.M.; Maesano, C.N.; Christoffersen, J.; Banerjee, S.; Gabriel, M.; Csobod, E.; Fernandes, E.D.; Annesi-Maesano, I.; Csobod, E.E.; Szuppinger, P. Indoor air pollution, physical and comfort parameters related to schoolchildren's health: Data from the european sinphonie study. Sci. Total Environ. 2020, 739, 139870. [CrossRef] [PubMed] 
7. Gao, X.M.; Jali, Z.M.; Aziz, A.R.A.; Hizaddin, H.F.; Buthiyappan, A.; Jewaratnam, J.; Bello, M.M. Inherent health oriented design for preventing sick building syndrome during planning stage. J. Build. Eng. 2021, 44, 103285. [CrossRef]

8. Aigbavboa, C.; Thwala, W.D. Performance of a green builidng's indoor environmental quality on building occupants in South Africa. J. Green Build. 2019, 14, 131-147. [CrossRef]

9. Jones, A.P. Indoor air quality and health. Atmos. Environ. 1999, 33, 4535-4564. [CrossRef]

10. Vardoulakis, S.; Giagloglou, E.; Steinle, S.; Davis, A.; Sleeuwenhoek, A.; Galea, K.S.; Dixon, K.; Crawford, J.O. Indoor exposure to selected air pollutants in the home environment: A systematic review. Int. J. Environ. Res. Pub. Health 2020, 17, 8972. [CrossRef]

11. Nordin, S. Mechanisms underlying nontoxic indoor air health problems: A review. Int. J. Hyg. Environ. Health 2020, 226, 113489. [CrossRef]

12. Tran, V.V.; Park, D.; Lee, Y.C. Indoor air pollution, related human diseases, and recent trends in the control and improvement of indoor air quality. Int. J. Environ. Res. Public Health 2020, 17, 2927. [CrossRef] [PubMed]

13. Fisk, W.J. How home ventilation rates affect health: A literature review. Indoor Air 2018, 28, 473-487. [CrossRef] [PubMed]

14. Hummon, N.P.; Doreian, P. Connectivity in a citation network: The development of DNA theory. Soc. Netw. 1989, 11, 39-63. [CrossRef]

15. Batagelj, V. Efficient algorithms for citation network analysis. arXiv 2003, arXiv:Cs/0309023.

16. Henrique, B.M.; Sobreiro, V.A.; Kimura, H. Building direct citation networks. Scientometrics 2018, 115, 817-832. [CrossRef]

17. Fu, H.L.; Wang, M.M.; Li, P.; Jiang, S.; Hu, W.; Guo, X.T.; Cao, M. Tracing knowledge development trajectories of the internet of things domain: A main path analysis. IEEE Trans. Ind. Inf. 2019, 15, 6531-6540. [CrossRef]

18. Toth, I.; Lazar, Z.I.; Varga, L.; Jarai-Szabo, F.; Papp, I.; Florian, R.V.; Ercsey-Ravasz, M. Mitigating ageing bias in article level metrics using citation network analysis. J. Inf. 2021, 15, 101105. [CrossRef]

19. Bergefurt, L.; Weijs-Perree, M.; Appel-Meulenbroek, R.; Arentze, T. The physical office workplace as a resource for mental health-a systematic scoping review. Build. Environ. 2022, 207, 108505. [CrossRef]

20. Sun, Y.X.; Hou, J.; Cheng, R.S.; Sheng, Y.; Zhang, X.Y.; Sundell, J. Indoor air quality, ventilation and their associations with sick building syndrome in chinese homes. Energ. Build. 2019, 197, 112-119. [CrossRef]

21. Finnegan, M.J.; Pickering, C.A.C.; Burge, P.S. The sick building syndrome-Prevalence studies. Brit. Med. J. 1984, $289,1573-1575$. [CrossRef]

22. Burge, S.; Hedge, A.; Wilson, S.; Bass, J.H.; Robertson, A. Sick building syndrome-A study of 4373 office workers. Ann. Occup. Hyg. 1987, 31, 493-504. [PubMed]

23. Norback, D.; Michel, I.; Widstrom, J. Indoor air- quality and personal factors related to the sick building syndrome. Scand. J. Work Environ. Health 1990, 16, 121-128. [CrossRef] [PubMed]

24. Norback, D.; Torgen, M.; Edling, C. Volatile organic- compounds, respirable dust, and personal factors related to prevalence and incidence of sick building syndrome in primary- schools. Br. J. Ind. Med. 1990, 47, 733-741. [CrossRef] [PubMed]

25. Skov, P.; Valbjorn, O. The sick building syndrome in the office environment-The Danish town hall study. Environ. Int. 1987, 13, 339-349. [CrossRef]

26. Skov, P.; Valbjorn, O.; Pedersen, B.V. Influence of personal characteristics, job-related factors and psychosocial factors on the sick building syndrome. Scand. J. Work Environ. Health 1989, 15, 286-295. [CrossRef]

27. Skov, P.; Valbjorn, O.; Pedersen, B.V. Influence of indoor climate on the sick building syndrome in an office environment. Scand. J. Work Environ. Health 1990, 16, 363-371. [CrossRef]

28. Norback, D.; Edling, C. Environmental, occupational, and personal factors related to the prevalence of sick building syndrome in the general-population. Br. J. Ind. Med. 1991, 48, 451-462. [CrossRef]

29. Teeuw, K.B.; Vandenbrouckegrauls, C.M.J.E.; Verhoef, J. Airborne gram-negative bacteria and endotoxin in sick building syndrome- A study on Dutch governmental office buildings. Arch. Intern. Med. 1994, 154, 2339-2345. [CrossRef]

30. Redlich, C.A.; Sparer, J.; Cullen, M.R. Sick- building syndrome. Lancet 1997, 349, 1013-1016. [CrossRef]

31. Bjornsson, E.; Janson, C.; Norback, D.; Boman, G. Symptoms related to the sick building syndrome in a general population sample: Associations with atopy, bronchial hyper- responsiveness and anxiety. Int. J. Tuberc. Lung Dis. 1998, 2, $1023-1028$.

32. Runeson, R.; Wahlstedt, K.; Wieslander, G.; Norback, D. Personal and psychosocial factors and symptoms compatible with sick building syndrome in the Swedish workforce. Indoor Air 2006, 16, 445-453. [CrossRef] [PubMed]

33. Menzies, R.; Tamblyn, R.; Farant, J.P.; Hanley, J.; Nunes, F.; Tamblyn, R. The effect of varying levels of outdoor- Air supply on the symptoms of sick building syndrome. N. Engl. J. Med. 1993, 328, 821-827. [CrossRef] [PubMed]

34. Stenberg, B.; Eriksson, N.; Hoog, J.; Sundell, J.; Wall, S. The sick- building-syndrome(SBS) in office- workers-A case-referent study of personal, psychosocial and building- related risk indicators. Int. J. Epidemiol. 1994, 23, 1190-1197. [CrossRef] [PubMed]

35. Seppanen, O.A.; Fisk, W.J.; Mendell, M.J. Association of ventilation rates and $\mathrm{CO}_{2}$ concentrations with health andother responses in commercial and institutional buildings. Indoor Air 1999, 9, 226-252. [CrossRef]

36. Wargocki, P.; Wyon, D.P.; Sundell, J.; Clausen, G.; Fanger, P.O. The effects of outdoor air supply rate in an office on perceived air quality, Sick Building Syndrome (SBS) symptoms and productivity. Indoor Air 2000, 10, 222-236. [CrossRef] [PubMed]

37. Wargocki, P.; Sundell, J.; Bischof, W.; Brundrett, G.; Fanger, P.O.; Gyntelberg, F.; Hanssen, S.O.; Harrison, P.; Pickering, A.; Seppanen, O.; et al. Ventilation and health in non-industrial indoor environments: Report from a European Multidisciplinary Scientific Consensus Meeting (EUROVEN). Indoor Air 2002, 12, 113-128. [CrossRef] [PubMed]

38. Norback, D. An update on sick building syndrome. Curr. Opin. Allergy CL 2009, 9, 55-59. [CrossRef] 
39. Sahlberg, B.; Gunnbjornsdottir, M.; Soon, A.; Jogi, R.; Gislason, T.; Wieslander, G.; Janson, C.; Norback, D. Airborne molds and bacteria, microbial volatile organic compounds (MVOC), plasticizers and formaldehyde in dwellings in three North European cities in relation to sick building syndrome (SBS). Sci. Total Environ. 2013, 444, 433-440. [CrossRef]

40. Lu, C.; Deng, Q.H.; Li, Y.G.; Sundell, J.; Norback, D. Outdoor air pollution, meteorological conditions and indoor factors in dwellings in relation to sick building syndrome (SBS) among adults in China. Sci. Total Environ. 2016, 560, 186-196. [CrossRef]

41. Ghaffarianhoseini, A.; AlWaer, H.; Omrany, H.; Ghaffarianhoseini, A.; Alalouch, C.; Clements-Croome, D.; Tookey, J. Sick building syndrome: Are we doing enough? Archit. Sci. Rev. 2018, 61, 99-121. [CrossRef]

42. Gyntelberg, F.; Suadicani, P.; Nielsen, J.W.; Skov, P.; Valbjorn, O.; Nielsen, P.A.; Schneider, T.; Jorgensen, O.; Wolkoff, P.; Wilkins, C.K.; et al. Dust and the sick building syndrome. Indoor Air 1994, 4, 223-238. [CrossRef]

43. Nordstrom, K.; Norback, D.; Akselsson, R. Effect of air humidification on the sick building syndrome and perceived indoor airquality in hospitals-A 4 month longitudinal- study. Occup. Environ. Med. 1994, 51, 683-688. [CrossRef] [PubMed]

44. Wargocki, P.; Wyon, D.P.; Baik, Y.K.; Clausen, G.; Fanger, P.O. Perceived air quality, Sick Building Syndrome (SBS) symptoms and productivity in an office with two different pollution loads. Indoor Air 1999, 9, 165-179. [CrossRef] [PubMed]

45. Apte, M.G.; Fisk, W.J.; Daisey, J.M. Associations between indoor $\mathrm{CO}_{2}$ concentrations and sick building syndrome symptoms in US office buildings: An analysis of the 1994-1996 BASE study data. Indoor Air 2000, 10, 246-257. [CrossRef]

46. Takigawa, T.; Wang, B.L.; Saijo, Y.; Morimoto, K.; Nakayama, K.; Tanaka, M.; Shibata, E.; Yoshimura, T.; Chikara, H.; Ogino, K.; et al. Relationship between indoor chemical concentrations and subjective symptoms associated with sick building syndrome in newly built houses in Japan. Int. Arch. Occup. Environ. Health 2010, 83, 225-235. [CrossRef]

47. Araki, A.; Kawai, T.; Eitaki, Y.; Kanazawa, A.; Morimoto, K.; Nakayama, K.; Shibata, E.; Tanaka, M.; Takigawa, T.; Yoshimura, T.; et al. Relationship between selected indoor volatile organic compounds, so-called microbial VOC, and the prevalence of mucous membrane symptoms in single family homes. Sci. Total Environ. 2010, 408, 2208-2215. [CrossRef]

48. AlWaer, H.; Speedie, J.; Cooper, I. Unhealthy Neighbourhood "Syndrome": A Useful Label for Analysing and Providing Advice on Urban Design Decision-Making? Sustainavility 2021, 13, 6232. [CrossRef]

49. Guo, X.T.; Fan, Z.Y.; Zhu, H.; Chen, X.Y.; Wang, M.M.; Fu, H.L. Willingness to Pay for Healthy Housing during the COVID-19 Pandemic in China: Evidence from Eye Tracking Experiment. Front. Public Health 2022. 